\title{
Investigation of mitochondrial DNA polymorphisms in patients with hematological malignancy
}

\section{Hematolojik maligniteli hastalarda mitokondriyal DNA polimorfizmlerinin araştırılması mitochondrial DNA polymorphisms}

\author{
Neslihan DUZKALE ${ }^{*} \square$, Cigdem YUCE KAHRAMAN² $\square$ Ilhami KIKI³ㅁ, Rahsan YILDIRIM ${ }^{4} \square$, \\ Gulden SINCAN ${ }^{3}$, Abdulgani TATAR ${ }^{2} \square$
}

1'Diskapi Yildirim Beyazit Training and Research Hospital, Department of Medical Genetics, Ankara / TURKEY ${ }^{2}$ Ataturk University, Faculty of Medicine, Department of Medical Genetics, Erzurum / TURKEY

${ }^{3}$ Ataturk University, Faculty of Medicine Department of Internal Medicine, Division of Hematology, Erzurum / TURKEY

${ }^{4}$ Medical Park Antalya Hospital Complex, Department of Internal Medicine, Division of Hematology, Antalya / TURKEY

\begin{abstract}
Aim: Mitochondrial DNA (mtDNA) polymorphisms can be considered as a molecular marker in susceptibility to various types of cancer. In this study, we aimed to investigate the potential relationship of mtDNA polymorphisms with disease etiopathogenesis in patients with hematological malignancy.

Material and Methods: This study was carried out with the participation of 80 patients diagnosed with hematological malignancy and 80 healthy individuals in the Department of Medical Genetics, Atatürk University. In all participants, 13 polymorphism regions of 6 coding genes of $m t D N A$ were investigated by Polymerase chain reaction restriction fragment length polymorphism (PCR-RFLP) method. SNPs evaluated in the study; NADH dehydrogenase subunit 5-13704 (C>T), Cytochrome b $15315(\mathrm{C}>\mathrm{T}), 12 \mathrm{~S}$ rRNA $740(\mathrm{G}>\mathrm{A})$ and 680 (T>C), Cytochrome C Oxidase I $7319(\mathrm{~T}>\mathrm{C}),-7444(\mathrm{G}>\mathrm{A})$, Cytochrome C Oxidase II $8252(\mathrm{C}>\mathrm{G}), 7660(\mathrm{G}>\mathrm{A}), 7975(\mathrm{~A}>\mathrm{G}), 8014(\mathrm{~A}>\mathrm{G}), 8113(\mathrm{C}>\mathrm{A}), 8152(\mathrm{G}>\mathrm{A})$ and tRNA lysine 8310 $(\mathrm{T}>\mathrm{C})$ were identified as.

Results: ND-5 13704 (C>T) polymorphism was statistically significant in patients with hematological malignancies compared to healthy controls $(p=0.001)$. There was no significant difference between patients and controls in other evaluated polymorphisms.

Conclusion: Although the findings obtained from this study suggest that mtDNA ND-5 13704 (C>T) polymorphism may play a role in the etiopathogenesis of hematological malignancies, large-scale studies are needed to determine the importance of this polymorphic region.
\end{abstract}

Keywords: Hematologic malignancy; Mitochondrial DNA; Polymorphism; NADH dehydrogenase

Corresponding Author*: Neslihan DUZKALE, Diskapi Yildirim Beyazit Training and Research Hospital, Department of Medical Genetics, Ankara / TURKEY E-mail: neslihanduzkale@gmail.com

ORCID: 0000-0001-6122-5316

Recevied: 01.04.2021 accepted: 28.05.2021

Doi: $10.18663 /$ tjcl.907688 


\section{Öz}

Amaç: Mitokondriyal DNA (mtDNA) polimorfizmleri, çeşitli kanser türlerine duyarlılıkta moleküler bir belirteç olarak düşünülebilir. Bu çalışmada, hematolojik malignite tanılı hastalarda mtDNA polimorfizmlerinin hastalık etyopatogenezi ile muhtemel ilişkisini araştırmayı amaçladık.

Gereç ve Yöntemler: Bu çalışma Atatürk Üniversitesi Tıbbi Genetik Anabilim Dalı'nda hematolojik malignite tanısı almış 80 hasta ve 80 sağlıklı bireyin katılımıyla gerçekleştirildi. Tüm katılımcılarda, mtDNA'nın 6 kodlama genindeki 13 polimorfizm bölgesi, PCR-RFLP yöntemi ile araştırıldı. Çalışmada değerlendirilen SNP'ler; NADH dehidrojenaz alt birimi 5-13704 (C >T), Sitokrom b 15315 (C>T), 12S rRNA 740 (G>A) ve 680 (T>C), Sitokrom C Oksidaz I 7319 (T>C), 7444 (G>A), Sitokrom C Oksidaz II $8252(C>G), 7660(G>A), 7975(A>G), 8014(A>G), 8113(C>A), 8152(G>A)$ ve tRNA lizin $8310(T>C)$ olarak tanımlandı.

Bulgular: ND-5 13704 (C>T) polimorfizmi, hematolojik maligniteli hastalarda sağlıklı kontrollere göre istatistiksel olarak anlamlı bulundu $(p=0,001)$. Değerlendirilen diğer polimorfizmlerde hastalar ve kontroller arasında anlamlı bir fark yoktu.

Sonuç: Bu çalışmadan elde edilen bulgular, mtDNA ND-5 13704 (C>T) polimorfizminin, hematolojik malignitelerin etiyopatogenezinde rol oynayabileceğini düşündürse de, bu polimorfik bölgenin önemini belirlemek için büyük ölçekli çalışmalara ihtiyaç duyulmaktadır.

Anahtar Kelimeler: Hematolojik malignite; Mitokondriyal DNA; Polimorfizm, NADH dehidrojenaz

\section{Introduction}

Mitochondria are cytoplasmic organelles that play a role in the regulation of many important physiological processes in the cell. It plays a role in the production of ATP required for the cell, modulation of the oxidation-reduction process called redox, production of reactive oxygen species (ROS), control of cytosolic calcium levels and Fe / S biogenesis, intrinsic pathway of apoptosis and the formation of some cytosolic precursors [1, 2]. The mitochondrial genome, which accounts for about $0.5-1 \%$ of the total DNA in the cell, contains 37 genes. In these genes, one single nucleotide polymorphism (SNP) is observed for every 13 base pair, these SNPs may cause an increased risk of various types of cancer according to the studies [3]. The mechanism underlying the relationship between specific mtDNA SNPs and malignancy susceptibility is still unclear [4]. It has been reported in the literature that sequence variants of mitochondrial NADH dehydrogenase, Cytochrome b, Cytochrome C Oxidase I, 12S rRNA, Cytochrome C Oxidase II and tRNA genes can affect the OXPHOS process, cause an increase in ROS production and eventually initiate carcinogenesis [5-8].

In this study, we aimed to examine 13 SNPs of these six genes from the mtDNAs of patients diagnosed with hematological malignancy using the Polymerase Chain Reaction-Restriction Fragment Length Polymorphism (PCR-RFLP) method and to investigate the possible importance of these SNPs in cancer etiopathogenesis.

\section{Material and Methods}

\section{Data of Patients}

This study was conducted in Medical Genetics Department of Ataturk University between September 2011 and December 2011 in order to determine the relationship between mtDNA polymorphisms and disease etiology in patients with hematological malignancy. According to the World Health Organization diagnostic criteria [9, 10], 80 patients between the ages of 18-82 who were diagnosed with acute myeloid/ lymphoid and chronic myeloid/lymphoid leukemia and 80 healthy individuals between the ages of 18-87 were included in this study. Information on the demographic and clinical characteristics of the patients was obtained from the patients and their medical records.

\section{Statement of Ethics}

Before the study written informed consent was obtained from the patients and healthy volunteers who participated in the study to publish all data about the study. This study was conducted considering ethical responsibilities according to the World Medical Association and the Declaration of Helsinki. The study was approved by the independent Ethics Committee of Ataturk University Medical Faculty Hospital (Document No:2011-08/7).

\section{Total DNA extraction}

DNA isolation from peripheral blood was performed according 
to the manufacturer's DNA-mini kit (Qiagen, Turkey) protocol. Isolated mtDNA samples were stored at $-20^{\circ} \mathrm{C}$. DNA quality was measured and standardized by spectrophotometry.

\section{PCR amplification of mtDNA fragment}

The SNP regions examined in this study are located in genes that play important roles in the OXHPOS pathway and are classified as "benign and likely benign" according to recent guidelines [11] (Tab.1).
In this research, one $0.5 \mathrm{ml} \mathrm{PCR} \mathrm{tube} \mathrm{was} \mathrm{labeled} \mathrm{for} \mathrm{each}$ individual. $50 \mu$ l of the mixture was prepared for PCR. $5 \mu \mathrm{I}$ DNA solution, $10 \mu \mathrm{l}$ sterile double distilled water, $14 \mu \mathrm{l}$ PCR master mix and $1.5 \mu$ l primer mix (Metabion, Germany) were used for the area concerned. While preparing the primary mixture; $5 \mu \mathrm{l}$ of each forward and reverse primer of the relevant region was taken and diluted with $90 \mu$ l distilled water (Tab.2).

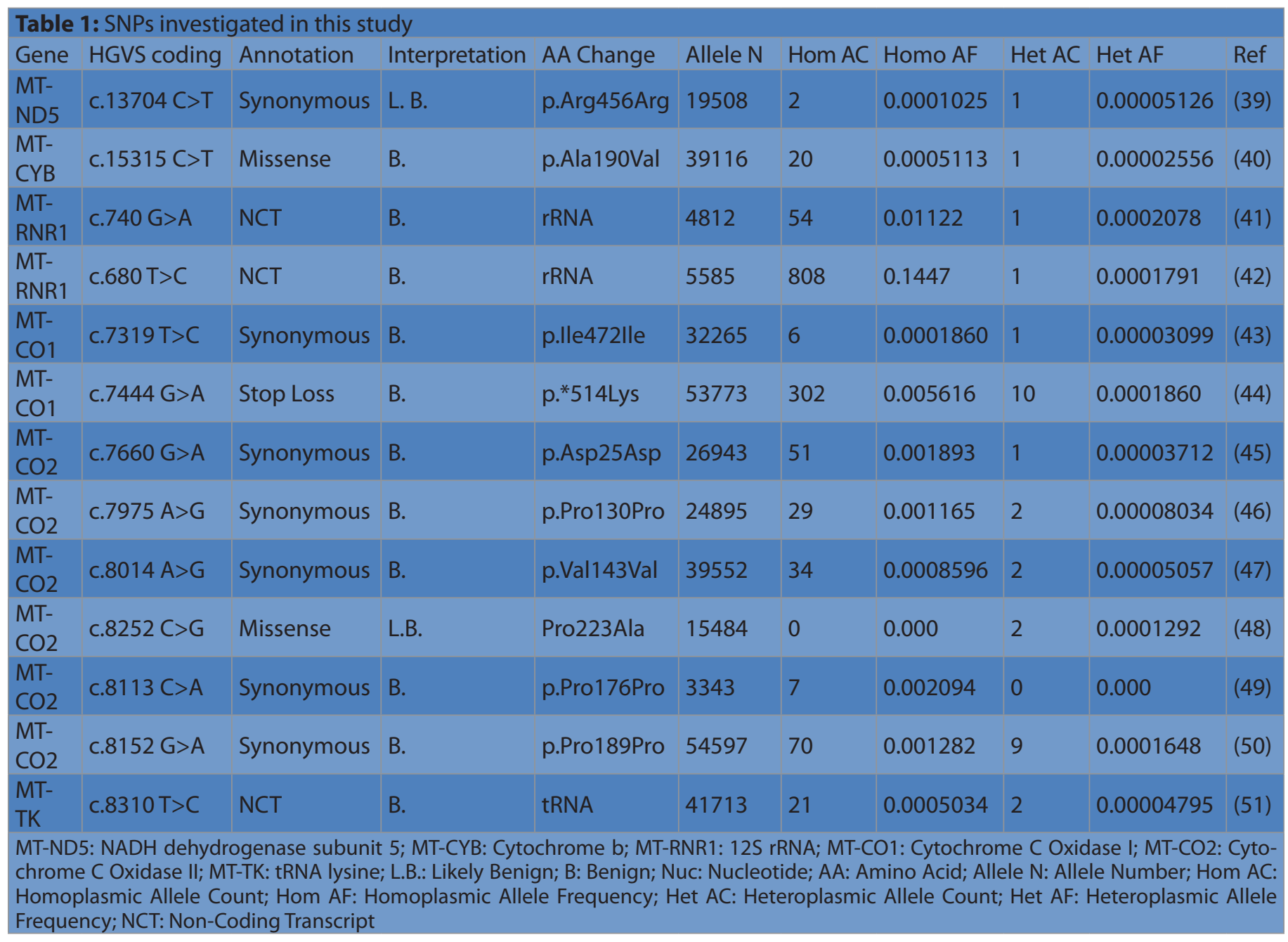

\begin{tabular}{|c|c|c|c|c|}
\hline Primer No & Genes & Primers & MtDNA Position & PCR product (bp) \\
\hline 1 & Sitokrom b & $\begin{array}{l}\text { Forward: 5'-ACATCGGCATTATCCTCCTG-3' } \\
\text { Reverse: 5'-GAGGGCGTCTTTGATTGTGT-3' }\end{array}$ & 15087-15436 & 350 \\
\hline 2 & ND5 & $\begin{array}{l}\text { Forward: 5'-ACATCGGCATTATCCTCCTG-3' } \\
\text { Reverse: 5'-GAGGGCGTCTTTGATTGTGT-3' }\end{array}$ & 13627-13955 & 328 \\
\hline 3 & $12 \mathrm{~S}$ rRNA & $\begin{array}{l}\text { Forward: 5'-GGTATGCACTTTTAACAGTCACC-3' } \\
\text { Reverse: 5'-ACTTGGGTTAATCGTGTGACC-3' }\end{array}$ & $412-921$ & 510 \\
\hline 4 & Sitokrom C Oksidaz I & $\begin{array}{c}\text { Forward: 5'-ACCCCGATGCATACACCA-3' } \\
\text { Reverse: 5'-GGACTAGGAAGCAGATAAGGAAA-3' }\end{array}$ & $7231-7700$ & 470 \\
\hline 5 & Sitokrom C Oksidaz II & $\begin{array}{l}\text { Forward: 5'-CTAATCTTCAACTCCTACATACTTCC-3' } \\
\text { Reverse: 5'-GCCATACGGTAGTATTTAGTTG-3' }\end{array}$ & 7931-8393 & 463 \\
\hline
\end{tabular}


In this study, XP Thermal Cycler (Bioer, China) device was used. PCR was performed with 35 cycles of denaturation: at $95^{\circ} \mathrm{C}$ for $1 \mathrm{~min}$; annealing: at $58^{\circ} \mathrm{C}$ for $1 \mathrm{~min}$; elongation: at $72^{\circ} \mathrm{C}$ for $1 \mathrm{~min}$ ". From obtained products, $4 \mu$ of each was taken and mixed with $0.4 \mu \mathrm{l}$ DNA dye (Metabion, Germany) and it was run at $120 \mathrm{~V}$ current for 20 minutes using $1.8 \%$ agarose gel in an electrophoresis system (Wealtec, USA). At the gel-imaging system (Syngene, USA) the band lengths were compared with marker DNA (Thermo Fermentas, Turkey) under UV light. It was decided that the PCR process was successful for the samples with the desired band lengths.

\section{Restriction enzymes application}

It was used the $\mathrm{NCBI}$ database for determine the sequence and location of the gene regions where the mtDNA SNPs to be investigated are located (https://www.ncbi.nlm.nih. gov/nuccore). NEBcutter V2.0 program was selected for determination of suitable enzyme and products to be used for cutting the obtained sequence (http://nc2.neb.com/ NEBcutter2/?name). For each sample $0.5 \mu \mathrm{L}$ SNP region determination enzyme (Thermo Fermentas, Turkey) and $8 \mu \mathrm{l}$ of PCR product were mixed. In the condition of $9 \mu$ of distilled water and $3 \mu$ l of buffer (Thermo Fermentas, Turkey) were added to this mixture. The resulting mixture was incubated at $37^{\circ} \mathrm{C}$ for 1 night (overnight). In the end, samples were run for 3 hours at $85 \mathrm{~V}$ current in a 3\% agarose gel and evaluated under UV light based on the band size for Marker DNA (Tab.3).

\begin{tabular}{|c|c|c|c|c|c|c|c|}
\hline $\begin{array}{l}\text { Primer } \\
\text { No }\end{array}$ & $\begin{array}{l}\text { Gene } \\
\text { SNP }\end{array}$ & $\begin{array}{l}\text { Restriction } \\
\text { Enzyme }\end{array}$ & $\begin{array}{l}\text { Enzyme } \\
\text { recognition sites }\end{array}$ & $\begin{array}{c}\text { PCR } \\
\text { Product }\end{array}$ & $\begin{array}{l}\text { Wild } \\
\text { Genotype }\end{array}$ & $\begin{array}{l}\text { Heteroplasmic } \\
\text { Genotype }\end{array}$ & $\begin{array}{l}\text { Homoplasmic } \\
\text { Genotype }\end{array}$ \\
\hline 1 & $\begin{array}{l}\text { Sitokrom b- } \\
15315(C>T)\end{array}$ & Mbol & $\begin{array}{l}5^{\prime} \ldots . . . \nabla \mathrm{GATC} \ldots \ldots 3^{\prime} \\
3^{\prime} \ldots \ldots . \text { CTAG } \Delta \ldots . .5^{\prime}\end{array}$ & $350 \mathrm{bp}$ & $\begin{array}{l}270 \mathrm{bp} \\
76 \mathrm{bp}\end{array}$ & $\begin{array}{l}350 \mathrm{bp} \\
270 \mathrm{bp} \\
76 \mathrm{bp}\end{array}$ & 350 bp \\
\hline 2 & $\begin{array}{c}\text { NADH dehydrogenase } \\
\text { subunit 5- } \\
13704(\mathrm{C}>\mathrm{T})\end{array}$ & Mval (BstNI) & $\begin{array}{l}5^{\prime} \ldots \ldots . . . C C \nabla W G G \ldots . .3^{\prime} \\
3^{\prime} \ldots \ldots .6 G W \Delta C C \ldots . .5^{\prime}\end{array}$ & $328 \mathrm{bp}$ & $\begin{array}{l}249 \mathrm{bp} \\
79 \mathrm{bp}\end{array}$ & $\begin{array}{l}328 \mathrm{bp} \\
249 \mathrm{bp} \\
79 \mathrm{bp}\end{array}$ & $328 \mathrm{bp}$ \\
\hline 3 & $\begin{array}{l}12 \mathrm{~S} \text { rRNA - } \\
740(\mathrm{G}>\mathrm{A})\end{array}$ & Mbol & $\begin{array}{l}5^{\prime} \ldots \ldots . \nabla \text { GATC } \ldots \ldots . .3^{\prime} \\
3^{\prime} \ldots \ldots . . \text { CTAG } \triangle \ldots . . .5^{\prime}\end{array}$ & $510 \mathrm{bp}$ & $\begin{array}{l}314 \mathrm{bp} \\
182 \mathrm{bp}\end{array}$ & $\begin{array}{l}510 \mathrm{bp} \\
314 \mathrm{bp} \\
182 \mathrm{bp}\end{array}$ & 510 bp \\
\hline 3 & $\begin{array}{l}12 \mathrm{~S} \text { rRNA - } \\
680(\mathrm{~T}>\mathrm{C})\end{array}$ & Ddel & 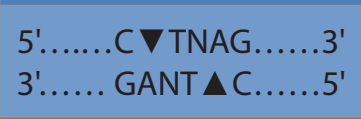 & $510 \mathrm{bp}$ & $\begin{array}{l}268 \mathrm{bp} \\
242 \mathrm{bp}\end{array}$ & $\begin{array}{l}510 \mathrm{bp} \\
268 \mathrm{bp} \\
242 \mathrm{bp}\end{array}$ & 510 bp \\
\hline 4 & $\begin{array}{l}\text { Sitokrom C Oksidaz I- } \\
7319(T>C)\end{array}$ & DdeI & 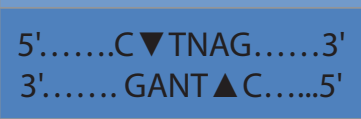 & 470 bp & 470 bp & $\begin{array}{l}470 \mathrm{bp} \\
381 \mathrm{bp} \\
85 \mathrm{bp}\end{array}$ & $\begin{array}{l}381 \mathrm{bp} \\
85 \mathrm{bp}\end{array}$ \\
\hline 4 & $\begin{array}{c}\text { Sitokrom C Oksidaz I- } \\
7444(\mathrm{G}>\mathrm{A})\end{array}$ & Xbal & $\begin{array}{l}5^{\prime} \ldots . . . . \mathrm{T} \nabla \mathrm{CTAGA} \ldots . . .3^{\prime} \\
3 ' \ldots . . . . \text { AGATC } \triangle \mathrm{T} \ldots . . .5^{\prime}\end{array}$ & 470 bp & $\begin{array}{l}260 \mathrm{bp} \\
210 \mathrm{bp}\end{array}$ & $\begin{array}{l}470 \mathrm{bp} \\
260 \mathrm{bp} \\
210 \mathrm{bp}\end{array}$ & 470 bp \\
\hline 4 & $\begin{array}{l}\text { Sitokrom C Oksidaz II- } \\
7660 \text { (G>A }\end{array}$ & Mbol & $\begin{array}{l}5^{\prime} \ldots \ldots . \nabla \text { GATC } \ldots . . .3^{\prime} \\
3^{\prime} \ldots \ldots . . . \text { CTAG } \triangle \ldots . .5^{\prime}\end{array}$ & 470 bp & $\begin{array}{l}427 b p \\
43 b p\end{array}$ & $\begin{array}{l}470 \text { bp } \\
427 \text { bp } \\
43 \text { bp }\end{array}$ & $470 \mathrm{bp}$ \\
\hline 5 & $\begin{array}{c}\text { Sitokrom C Oksidaz II- } \\
7975(A>G)\end{array}$ & Mval (BstNI) & $\begin{array}{l}5^{\prime} \ldots \ldots . . . C C \nabla W G G \ldots . .3^{\prime} \\
3^{\prime} \ldots \ldots . .6 G W \Delta C C \ldots . .5^{\prime}\end{array}$ & $463 \mathrm{bp}$ & $\begin{array}{l}419 \text { bp } \\
44 \text { bp }\end{array}$ & $\begin{array}{l}463 \mathrm{bp} \\
419 \mathrm{bp} \\
44 \mathrm{bp}\end{array}$ & $463 \mathrm{bp}$ \\
\hline 5 & $\begin{array}{l}\text { tRNA lysine- } \\
8310 \text { (T>C) }\end{array}$ & Ddel & $\begin{array}{l}5^{\prime} \ldots \ldots . . \mathrm{C} \nabla \mathrm{TNAG} \ldots . .3^{\prime} \\
3^{\prime} \ldots \ldots . \mathrm{GANT} \Delta \mathrm{C} \ldots \ldots .5^{\prime}\end{array}$ & $463 \mathrm{bp}$ & $\begin{array}{l}379 \mathrm{bp} \\
81 \mathrm{bp}\end{array}$ & $\begin{array}{l}463 \mathrm{bp} \\
379 \mathrm{bp} \\
81 \mathrm{bp}\end{array}$ & $463 \mathrm{bp}$ \\
\hline 5 & $\begin{array}{l}\text { Sitokrom C Oksidaz II- } \\
8014(A>G)\end{array}$ & Rsal & $\begin{array}{l}5^{\prime} \ldots . . . \mathrm{GT} \nabla \mathrm{AC} \ldots . .3^{\prime} \\
3^{\prime} \ldots . . . \mathrm{CA} \triangle \mathrm{TG} \ldots .5^{\prime}\end{array}$ & 463 bp & $\begin{array}{l}380 \mathrm{bp} \\
83 \mathrm{bp}\end{array}$ & $\begin{array}{l}463 \mathrm{bp} \\
380 \mathrm{bp} \\
83 \mathrm{bp}\end{array}$ & $463 \mathrm{bp}$ \\
\hline 5 & $\begin{array}{c}\text { Sitokrom C Oksidaz II- } \\
\quad 8252(\mathrm{C}>\mathrm{G})\end{array}$ & Haelll & $\begin{array}{l}5^{\prime} \ldots . . . \mathrm{GG} \nabla \mathrm{CC} \ldots . .3^{\prime} \\
3^{\prime} \ldots \ldots \mathrm{CC} \triangle \mathrm{GG} \ldots . .5^{\prime}\end{array}$ & 463 bp & $\begin{array}{l}321 \mathrm{bp} \\
142 \mathrm{bp}\end{array}$ & $\begin{array}{l}463 \mathrm{bp} \\
321 \mathrm{bp} \\
142 \mathrm{bp}\end{array}$ & $463 \mathrm{bp}$ \\
\hline 5 & $\begin{array}{c}\text { Sitokrom C Oksidaz II- } \\
8113(\mathrm{C}>\mathrm{A}) \\
8152(\mathrm{G}>\mathrm{A})\end{array}$ & Mspl & $\begin{array}{l}5^{\prime} \ldots . . . C \nabla C G G \ldots . .3^{\prime} \\
3^{\prime} \ldots . . . G G C \Delta C \ldots . .5^{\prime}\end{array}$ & $463 \mathrm{bp}$ & $\begin{array}{c}281 \mathrm{bp} \\
182 \mathrm{bp} \\
\text { OR } \\
243 \mathrm{bp} \\
182 \mathrm{bp} \\
38 \mathrm{bp}\end{array}$ & $\begin{array}{c}463 \mathrm{bp} \\
281 \mathrm{bp} \\
182 \mathrm{bp} \\
\text { OR } \\
463 \mathrm{bp} \\
243 \mathrm{bp} \\
182 \mathrm{bp} \\
38 \mathrm{bp}\end{array}$ & $463 \mathrm{bp}$ \\
\hline
\end{tabular}




\section{Data analysis}

Mitomap database (https://www.mitomap.org/MITOMAP) and Alamut program (https://www.interactive-biosoftware.com) were used in the analysis of all SNP regions. The haplogroup frequencies of the variants were determined using theV3.1 version of the GnomAD database (https://gnomad.broadinstitute.org/). The guidelines in the final manual of ACMG/AMG were followed for annotations of all sequence variants [11].

\section{Statistical analyses}

SPSS (IBM SPSS Statistics 24) program was used for the statistical evaluation of all results obtained. Examination of the relations of two qualitative variables was done with "x2-cross tables". A p-value of 0.05 or less at the statistical significance level was accepted as a significant result.

\section{Results}

Among 80 patients included in this study, 30 had a diagnosis of chronic myeloid leukemia (CML), 20 acute myeloid leukemia $(A M L), 18$ chronic lymphocytic leukemia (CLL), and 12 acute lymphoblastic leukemia (ALL). Among these patients 38 $(47.5 \%)$ were female, $42(52.5 \%)$ were male and their mean age was calculated as $48.60 \pm 18.7$ (range:18-82). In the control group, there were 80 healthy individuals, 39 (48.7\%) females and 41 (51.3\%) males. Their mean age was calculated as 41.79 \pm 18.5 (range: 18-87). Among the SNPs evaluated in the study, Cytochrome b-15315 (C>T), 12S rRNA -740 (G>A), 12S rRNA680 ( $\mathrm{T}>\mathrm{C})$, Cytochrome C Oxidase I-7319 (T>C), Cytochrome C Oxidase I-7444 (G>A), Cytochrome C Oxidase II-7660 (G>A), Cytochrome C Oxidase II-7975 (A>G), tRNA lysine-8310 (T>C), Cytochrome C Oxidase II-8014 (A>G), Cytochrome C Oxidase II-8113 (C>A) and Cytochrome C Oxidase II-8152 (G>A); It was observed normal for patient and control groups.

The Cytochrome C Oxidase II region 8252 (C>G) polymorphism was observed as homoplasmic in $4(5 \%)$ of the patients and heteroplasmic in 11 (13.75\%). In the control group, 3 people (3.75\%) were found to be homoplasmic and 10 (12.5\%) were heteroplasmic in terms of this polymorphism. No significant difference was found by the statistical comparison of both groups $(p=0.895)$ (Fig.1).

In terms of 13704 (C>T) polymorphism on ND5 region; only 1 (1.25\%) person in the control group and 12 (15\%) people in the patient group were found to be homoplasmic. Homoplasmy is statistically significant in the patient group compared to the healthy controls group $(p=0.001)$. This polymorphism showed no significant difference between patient subgroups and gender (Fig.2).

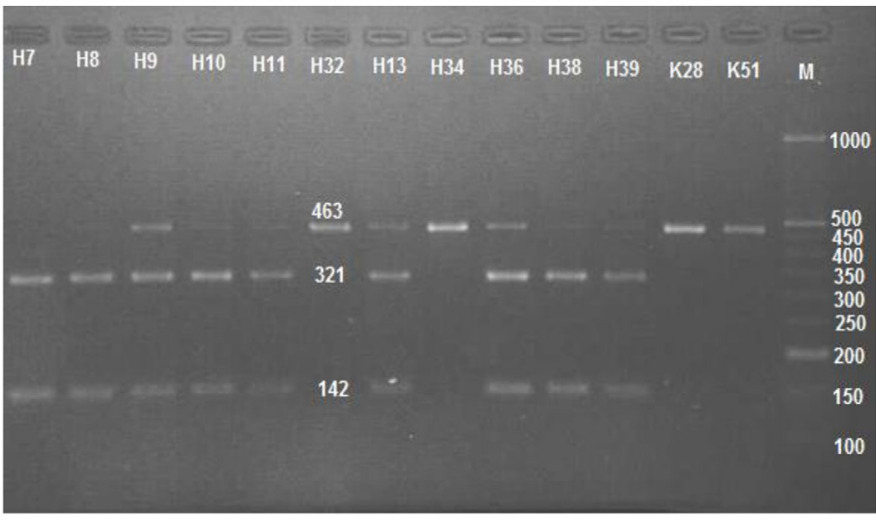

Figure 1: Agarose gel image of Cytochrome C Oxidase II region 8252 C > G polymorphism.

Figure 1 Legend: $M$ : Marker DNA; $\mathrm{H}$ : Patient sample; K: Control sample; H7, H8, H10, H11, H38, H39 wild genotype; H32, H34, K28, K51 homoplasmic genotype; $\mathrm{H} 9, \mathrm{H} 13$, H36 heteroplasmic genotype.

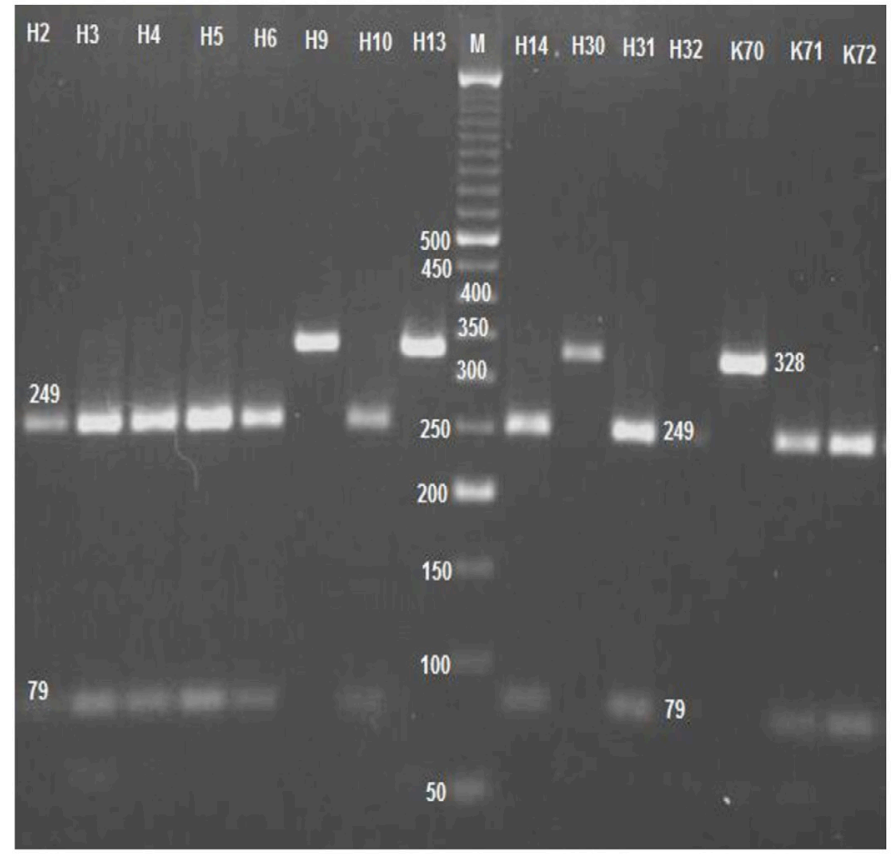

Figure 2: Agarose gel image of ND5 13704C $>$ T polymorphism.

Figure 2 Legend: M: Marker DNA; H: Patient sample; K: Control sample; $\mathrm{H} 2, \mathrm{H} 3, \mathrm{H} 4, \mathrm{H} 5, \mathrm{H} 6, \mathrm{H} 10, \mathrm{H} 14, \mathrm{H} 31, \mathrm{H} 32, \mathrm{~K} 71, \mathrm{~K} 72$ wild genotype; $\mathrm{H} 9, \mathrm{H} 13, \mathrm{H} 30$ ve $\mathrm{K} 70$ homoplasmic genotype.

\section{Discussion}

Most of the human mitochondrial genome contains genes that encode as opposed to the nuclear genome, and the evolutionary rate of the mitochondrial genome is 5-10 times greater than the nuclear genome. Therefore, it is thought that mitochondrial genome polymorphisms may contribute to functional differences between individuals in terms of bioenergetic efficiency, metabolic rate, oxygen consumption and ROS production compared to the nuclear genome [12]. 
It is shown that various polymorphisms could be effective in the carcinogenesis process by increasing ROS production. Increased ROS levels may cause activation of an oncogenic pathway, which is a risk factor in cancer development, as well as changes in the efficacy of an apoptotic reaction that has a protective effect in the last stages of cancer development $[13,14]$. Many parameters related to nuclear DNA, which is known to be important in the diagnosis and progression of the disease in hematological malignancies, have been defined [15]. In addition, in this disease group, various mutations and polymorphisms associated with the disease have been reported in mitochondrial DNA. In studies investigating the relationship between mtDNA polymorphisms and cancer; it has been argued that these variants may be important for determining DNA damage and individual susceptibility to carcinogens and can be considered as a molecular marker in various types of cancer [16]. These variations have shown that not only the risk of developing cancer, but also the occurrence of cancer-related symptoms, cancer treatment, and disease outcomes $[2,17]$.

The importance of mtDNA variants in hematological malignancies was first described by Clayton et al. in 1967, with a study conducted on leukemia patients. They argued that mtDNA has an important role in the etiology and treatment of acute and chronic leukemias [18]. In subsequent studies, Gatterman et al. suggested that mtDNA variants may contribute to the development of leukemia by increasing clonal expression in myelodysplastic syndrome (MDS) patients [19]. Wulfert et al. found a high proportion of mtDNA variants in patients with MDS and myeloproliferative disease. These variants concentrated in the control region of tRNA and rRNA, it has been detected less in the coding genes regions [20]. Similarly, in the studies of Yao et al. on leukemia patients, mtDNA variations were mostly observed in the control region [21]. In other studies; it has been claimed that the variations detected in D-Loop, the control region of mtDNA, contribute to the carcinogenesis process and are significantly associated with disease progression [22-24]. Cerezo et al. argued that various variants detected in mtDNAs of CLL patients may cause mtDNA instability and that these variants may contribute to the tumoral process even if they cannot be shown as the primary cause of CLL [25]. Carew et al. also detected many polymorphisms and mutations in the mtDNAs of CLL patients. In these patients after chemotherapy, there was an increase in mutation density. A positive correlation between superoxide anion production and mtDNA mutations has been observed [26]. Grist et al. in AML and ALL patients [27], Shin et al. in myelodysplasia patients [28], and Monnat et al. in leukemia and lymphoma cell lines [29] found various mutations and SNPs of mtDNA in their studies. Linnartz et al. identified various variants in genes encoding rRNA, tRNA and polypeptide in mtDNAs of AML patients developing secondary MDS and claimed that these variants may have a role in malignancy development [30]. He et al. identified many mtDNA variants in leukemia patients and specifically claimed that a variant in the cytochrome b region could be a clonal marker [31].

In this study, 13 SNPs in six gene of encoding mtDNA in 80 patients with hematological malignancies were examined by PCR-RFLP method. PCR-RFLP method was preferred because it is a reliable, sensitive and inexpensive method that does not require any funding for us. The limitations of this study were the heterogeneity of subgroup diagnoses of hematologic malignancy patients and the relatively small size of our case series, and the inability to rule out environmental and / or individual factors that could cause cancer susceptibility. Although there are mtDNA studies in hematological malignancy in the literature, the selected SNPs of our study were not studied and there is no information about their importance in hematological malignancies. In our study, evaluated SNPs are m.15315C $>\mathrm{T}, \mathrm{m.740G}>\mathrm{A}$, m.680T $>C, m .7319 T>C, m .7444 G>A, m .7660 G>A, m .7975 A>G$, m.8310T $>C, m .8014 A>G, m .8113 C>A, m .8152 G>A$, and all of them were observed normal for the patient and control groups. Although individuals with heteroplasmic and homoplasmic genotype were found in the patient and control groups in the investigation of Cytochrome C Oxidase II-8252 ( $\mathrm{C}>\mathrm{G})$ polymorphism, it showed no statistically significant $(p=0.895)$.

One of the regions of the oxidative phosphorylation system (OXPHOS) that contains common defects is the last component of the electron transport chain of cytochrome c oxidase and provides the transfer of electrons from cytochrome c to oxygen. Larger-scale studies are necessary to explain the possible role of SNPs in this region as well as other coding gene regions, due to its indisputable importance in OXPHOS in cancer investigation. In our study, ND-5 13704 (C>T) polymorphism of the Complex I region was found to be significantly positive in patients diagnosed with hematological malignancy compared to healthy controls $(p=0.001)$. In literature genomic changes of Complex I have been reported in many cancer patients It has been suggested that SNPs in this region cause oxidative damage by causing an increase in ROS production and may facilitate the development of neoplastic transformation and metastasis $[32,33]$. The polymorphisms of this gene was studied for the first time by Canter et al. and an increased risk of breast cancer was observed in polymorphic women [32]. This region SNPs have also shown an increased risk of prostate and esophageal cancer [33]. La Biche et al. claimed that the expression of the ND5 Complex I subunit in metastatic lymphoma cells was increased compared to nonmetastatic cells and that increased 
ND5 expression may play a role in lymphoma metastasis [34, 35]. Studies on these Complex I respiratory defects have shown an increase in the levels of bcl-2, an anti-apoptotic protein, and a decrease in Bax, a pro-apoptotic protein, in cells [36, 37]. Allegra et al. suggested that Complex I plays an important role in the metabolic processing of carcinogens and alterations in the function of this complex may contribute to the accumulation of mutagens [33]. Vanniarajan et al. claimed that the ND5 gene region is the hot spot region of the mitochondrial genome [38].

\section{Conclusion}

In our study, the presence of this polymorphism in the ND5 region, known as a hot spot in the literature, was found to be statistically significantly higher in patients compared to healthy ones. As a result, the 13704 (C>T) polymorphism in the ND5 region may play a role in the carcinogenesis process and contribute to the formation of hematological malignancy.

\section{Declaration of conflict of interest}

The authors declare that they have no conflict of interest.

\section{Funding}

This research was supported by Ataturk University Scientific Research Project (2009/305). Findings from the study were presented at the 62nd Annual Meeting of the American Society for Human Genetics (ASHG).

\section{Availability of data and materials}

The data are available on special request.

\section{References}

1. Lane N, Martin W. The energetics of genome complexity. Nature. 2010; 467: 929-34.

2. Wallace DC. Mitochondria and cancer. Nature Reviews Cancer. 2012; 12 :685-98.

3. Fernández-Silva P, Enriquez JA, Montoya J. Replication and transcription of mammalian mitochondrial DNA. Experimental physiology. 2003; 88 :41-56.

4. Singh KK, Kulawiec M. Mitochondrial DNA polymorphism and risk of cancer. Cancer Epidemiology: Springer; 2009: 291-303.

5. Hertweck KL, Dasgupta S. The landscape of mtDNA modifications in cancer: a tale of two cities. Frontiers in oncology. 2017; 7: 262.

6. Hüttemann M, Lee I, Grossman LI, et al. Phosphorylation of mammalian cytochrome $c$ and cytochrome c oxidase in the regulation of cell destiny: respiration, apoptosis, and human disease. Mitochondrial Oxidative Phosphorylation: Springer; 2012: 237-64.

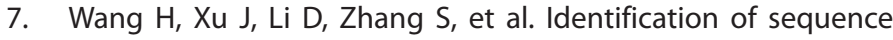
polymorphisms in the mitochondrial cytochrome c oxidase genes as risk factors for hepatocellular carcinoma. Journal of clinical laboratory analysis. 2018; 32: 22299.
8. Meng $\mathrm{X}-\mathrm{L}$, Meng $\mathrm{H}$, Zhang $\mathrm{W}$, et al. The role of mitochondrial tRNA variants in female breast cancer. Mitochondrial DNA Part A. 2016; 27: 3199-201.

9. Vardiman JW, Thiele J, Arber DA, et al. The 2008 revision of the World Health Organization (WHO) classification of myeloid neoplasms and acute leukemia: rationale and important changes. Blood. 2009; 114: 937-51.

10. Campo E, Swerdlow SH, Harris NL, et al. The 2008 WHO classification of lymphoid neoplasms and beyond: evolving concepts and practical applications. Blood, The Journal of the American Society of Hematology. 2011; 117: 5019-32.

11. McCormick EM, Lott MT, Dulik MC, et al. Specifications of the ACMG/AMP standards and guidelines for mitochondrial DNA variant interpretation. Human Mutation. 2020.

12. Andrews RM, Kubacka I, Chinnery PF, Lightowlers RN, Turnbull DM, Howell N. Reanalysis and revision of the Cambridge reference sequence for human mitochondrial DNA. Nature genetics. 1999; 23: 147.

13. Lu J, Qian Y, Li Z, et al. Mitochondrial haplotypes may modulate the phenotypic manifestation of the deafness-associated $12 \mathrm{~S}$ rRNA 1555A> G mutation. Mitochondrion. 2010; 10: 69-81.

14. Beckstead WA, Ebbert MT, Rowe MJ, et al. Evolutionary pressure on mitochondrial cytochrome $b$ is consistent with a role of Cytbl7T affecting longevity during caloric restriction. PLoS One. 2009; 4: 5836.

15. Öz Ö. JAK2 V617F Mutation Frequency in Chronic Myeloproliferative Disease Cases. Harran University Faculty of Medicine Journal. 2019; 16: 492-5.

16. Goode EL, Ulrich CM, Potter JD. Polymorphisms in DNA repair genes and associations with cancer risk. Cancer Epidemiology and Prevention Biomarkers. 2002; 11: 1513-30.

17. Parr RL, Dakubo GD, Thayer RE, et al. Mitochondrial DNA as a potential tool for early cancer detection. Human genomics. 2006; 2: 252.

18. Clayton DA, Vinograd J. Complex mitochondrial DNA in leukemic and normal human myeloid cells. Proceedings of the National Academy of Sciences. 1969; 62: 1077-84.

19. Gattermann N. From sideroblastic anemia to the role of mitochondrial DNA mutations in myelodysplastic syndromes. Leukemia research. 2000; 24: 141-51.

20. Wulfert M, Küpper AC, Tapprich C, et al. Analysis of mitochondrial DNA in 104 patients with myelodysplastic syndromes. Experimental hematology. 2008; 36: 577-86.

21. Yao Y-G, Ogasawara Y, Kajigaya $S$, et al. Mitochondrial DNA sequence variation in single cells from leukemia patients. Blood. 2007; 109: 756-62.

22. Zhou J, Gou H, Ye Y, et al. Sequence variations of mitochondrial DNA D-loop region in patients with acute myeloid leukemia. Oncology letters. 2017; 14: 6269-76. 
23. Lee $H$, Geng $C$, Cheng M, et al. Single nucleotide polymorphisms in the mitochondrial displacement loop and age-at-onset of familial breast cancer. Mitochondrial DNA Part A. 2016; 27: 3082-5.

24. Li S, Wan P, Peng T, et al. Associations between sequence variations in the mitochondrial DNA D-loop region and outcome of hepatocellular carcinoma. Oncology letters. 2016; 11:3723-8.

25. Cerezo M,BandeltH-J,Martín-Guerrerol, etal.High mitochondrial DNA stability in B-cell chronic lymphocytic leukemia. PloS one. 2009; 4: 7902.

26. Carew J, Zhou Y, Albitar M, et al. Mitochondrial DNA mutations in primary leukemia cells after chemotherapy: clinical significance and therapeutic implications. Leukemia. 2003; 17: 1437-47.

27. Grist SA, Lu X, Morley AA. Mitochondrial mutations in acute leukaemia. Leukemia. 2004; 18: 1313-6.

28. Shin MG, Kajigaya S, Levin BC, et al. Mitochondrial DNA mutations in patients with myelodysplastic syndromes. Blood, The Journal of the American Society of Hematology. 2003; 101: 3118-25.

29. Monnat RJ, Maxwell CL, Loeb LA. Nucleotide sequence preservation of human leukemic mitochondrial DNA. Cancer research. 1985; 45: 1809-14.

30. Linnartz B, Anglmayer R, Zanssen S. Comprehensive scanning of somatic mitochondrial DNA alterations in acute leukemia developing from myelodysplastic syndromes. Cancer research. 2004; 64: 1966-71.

31. He L, Luo L, Proctor S, et al. Somatic mitochondrial DNA mutations in adult-onset leukaemia. Leukemia. 2003; 17: 2487-91.

32. Canter JA, Kallianpur AR, Parl FF, et al. Mitochondrial DNA G10398A polymorphism and invasive breast cancer in AfricanAmerican women. Cancer research. 2005; 65: 8028-33.

33. Allegra E, Garozzo A, Lombardo N, et al. Mutations and polymorphisms in mitochondrial DNA in head and neck cancer cell lines. Acta otorhinolaryngologica italica. 2006; 26: 185.

34. LaBiche RA, Yoshida M, Gallick GE, et al. Gene expression and tumor cell escape from host effector mechanisms in murine large cell lymphoma. Journal of cellular biochemistry. 1988; 36: 393-403.

35. LaBiche RA, Demars M, Nicolson GL. Transcripts of the mitochondrial gene ND5 are overexpressed in highly metastatic murine large cell lymphoma cells. Vivo. 1992; 6: 317-24.

36. Bargou RC, Daniel PT, Mapara MY, et al. Expression of the bcl-2 gene family in normal and malignant breast tissue: low bax-a expression in tumor cells correlates with resistance towards apoptosis. International journal of cancer. 1995; 60: 854-9.

37. Binder C, Marx D, Binder L, Schauer A, Hiddemann W. Expression of Bax in relation to $\mathrm{BCl}-2$ and other predictive parameters in breast cancer. Annals of oncology. 1996; 7: 129-33.
38. Vanniarajan A, Nayak D, Reddy AG, et al. Clinical and genetic uniqueness in an individual with MELAS. American Journal of Medical Genetics Part B: Neuropsychiatric Genetics. 2006; 141:440-4.

39. Tanaka M, Ozawa T. Strand asymmetry in human mitochondrial DNA mutations. Genomics. 1994; 22: 327-35.

40. Marcus JH, Posth C, Ringbauer H, et al. Genetic history from the Middle Neolithic to present on the Mediterranean island of Sardinia. Nature communications. 2020; 11: 1-14.

41. Finnilä S, Lehtonen MS, Majamaa K. Phylogenetic network for European mtDNA. The American Journal of Human Genetics. 2001; 68: 1475-84.

42. Mishmar D, Ruiz-Pesini E, Golik P, et al. Natural selection shaped regional mtDNA variation in humans. Proceedings of the National Academy of Sciences. 2003; 100: 171-6.

43. van Oven M. Revision of the mtDNA tree and corresponding haplogroup nomenclature. Proceedings of the National Academy of Sciences. 2010; 107: 38-9.

44. Dobrowolski SF, Gray J, Miller T, et al. Identifying sequence variants in the human mitochondrial genome using high-resolution melt (HRM) profiling. Human mutation. 2009; 30: 891-8.

45. Batini C, Lopes J, Behar DM, et al. Insights into the demographic history of African Pygmies from complete mitochondrial genomes. Molecular biology and evolution. 2011; 28: 1099-110.

46. Hamblet NS, Ragland B, Ali M, et al. Mutations in mitochondrialencoded cytochrome c oxidase subunits I, II, and III genes detected in Alzheimer's disease using single-strand conformation polymorphism. Electrophoresis. 2006; 27: 398-408.

47. Gómez-Durán A, Pacheu-Grau D, López-Gallardo E, et al. Unmasking the causes of multifactorial disorders: OXPHOS differences between mitochondrial haplogroups. Human molecular genetics. 2010; 19: 3343-53.

48. Loo J-H, Trejaut JA, Yen J-C, et al. Genetic affinities between the Yami tribe people of Orchid Island and the Philippine Islanders of the Batanes archipelago. BMC genetics. 2011; 12: 21.

49. Ruvolo $M$, Zehr S, von Dornum $M$, et al. Mitochondrial COll sequences and modern human origins. Molecular Biology and Evolution. 1993; 10: 1115-35.

50. Kumar S, Bellis C, Zlojutro M, et al. Large scale mitochondrial sequencing in Mexican Americans suggests a reappraisal of Native American origins. BMC Evolutionary Biology. 2011; 11: 293.

51. Zsurka G, Schröder R, Kornblum C, et al. Tissue dependent cosegregation of the novel pathogenic G12276A mitochondrial tRNALeu (CUN) mutation with the A185G D-loop polymorphism. Journal of Medical Genetics. 2004; 41: 124. 